\title{
Effect of different levels of 3, 5,3'-triiodo-L-thyronine Administration in a dry diet on rearing of Whitefish (Coregonus lavaretus L., Coregoninae) Larvae
}

\author{
Paweł Poczyczyński ${ }^{1}$, Andrzej Mamcarz ${ }^{2 \star}$ and Jacek Kozłowski ${ }^{1}$ \\ ${ }^{\prime}$ Department of Fish Biology and Pisciculture, University of Warmia and Mazury, Olsztyn, Poland \\ ${ }^{2}$ Department of Lake and River Fisheries, University of Warmia and Mazury, Olsztyn, Poland
}

\section{Article Info}

\section{*Corresponding author: \\ Andrzej Mamcarz \\ Department of Lake and Rivers Fisheries University of Warmia \& Mazury, Olsztyn Poland \\ Email: mamcarz@uwm.edu.pl}

Received: October 6, 2017

Accepted: November 21, 2017

Published: November 27, 2017

Citation: Poczyczynski P, Mamcarz A, Kozlowski J. Effect of different levels of 3, 5, 3 '-triiodo-L-thyronine Administration in a dry diet on rearing of Whitefish (Coregonus lavaretus L., Coregoninae) Larvae. Madridge J Aquac Res Dev. 2017; 1(1): 31-34.

doi: $10.18689 / \mathrm{mjard}-1000106$

\section{Copyright: @ 2017 The Author(s). This work is licensed under a Creative Commons Attribution 4.0 International License, which permits unrestricted use, distribution, and reproduction in any medium, provided the original work is properly cited.}

Published by Madridge Publishers

\begin{abstract}
Laboratory rearing of whitefish (Coregonus lavaretus L.) larvae was carried out in water temperature of $14 \pm 1^{\circ} \mathrm{C}$. Larvae were fed exclusively on dry diet with addition of 3,5,3' triiodo-L-thyronine (T3) as a potential growth stimulator. Experimental groups received 0.5, 1.5, 3.5 and $10 \mathrm{ppm} \mathrm{T3}$, respectively. Control group was fed with no hormone. Experiment lasted for 20 days. At the end of the experiment larvae receiving 1.5 ppm T3 in the dry diet were heavier, but no longer $(P<0.05)$ in comparison with other groups (with exception of $0.5 \mathrm{ppm}$ group). There was no statistical difference in mortality between experimental groups. We conclude that the best results for enhancing larval growth were obtained at dose of $1.5 \mathrm{ppm}$ T3.
\end{abstract}

Keywords: Coregonus lavaretus L; Dry diet; Feed components; Hormone levels.

\section{Introduction}

Supplementation the feeds with small amounts of substances stimulating fish growth and decreasing the feeding coefficient (especially some hormones) is a method to increase the dry diet efficiency without changing of proportions of the major feed components. Many experiments confirmed stimulating effect of using androgens in fish feeding [1-7]. Other hormonal growth stimulators, like somatotropin [8], or triiodothyronine [9-12] were used occasionally, so far.

Using of different hormones in fish feeding in intensive aquaculture [13-17] is often considered in public opinion as possible danger for consumer's health [18-21], and restricted in different countries. In case of larval fish, reared maximally for 1-2 months before stocking to the nature, this problem should not be seen similarly. After coming to the natural life and habitat reared fish will transform to normal metabolism, so effect of stimulators (with exception of genetic therapy) would be cancelled. But, accelerating of larval development and growth with the use of stimulators may be an important tool for reducing of the most critical phases of fish ontogeny and preparing larger fish to stock.

"Division of competition" between thyroid hormones (3,5,3'-triiodothyronine - T3 and thyroxine - T4) is unclear in fish metabolism. Probably their functions have agreed to a considerable degree. The use of T3 in our experiment was connected with the fact, that in contrast to $\mathrm{T} 4$, this hormone may be effectively absorbed from the intestinal lumen $[4,22]$.

The aim of the experiment was: 1) to test the effect of a dry diet supplemented with $3,5,3^{\prime}$ triiodothyronine on larval rearing, and 2) to designate the best level of the hormone supplementation in coregonid starter diet. 


\section{Materials and Methods}

3,5,3'-triiodo-I-thyronine (T3) (produced by Sigma Corporation, St. Louis, USA) was added to the experimental diet. Control feed design was the same like the starter diet for coregonid fish used previously $[23,24]$, ie. yeast $(50 \%)$, lyophilized beef liver $(36 \%$, wheat meal $(4 \%)$, fish oil $(2 \%)$, soya oil $(2 \%)$, vitamin mixture (5\%), and mineral mixture (1\%). Food particle size was $0.1 \mathrm{~mm}$ during the first 10 days and then $-0.1-0.2 \mathrm{~mm}$. There were differences in the hormone level only. T3 doses were respectively $0.5,1.5,3.5$ and $10 \mathrm{ppm}$. Control diet was with no addition of the hormone.

Whitefish (Coregonus lavaretus) larvae with initial weight of $3.51 \mathrm{mg}$ and length of $91 \mathrm{~mm}$, originated from Fish Farm Szwaderki (Olsztyn District, Northern Poland). After thermal acclimation, they were divided into six groups in three replicates and located in 18 tanks (of volume of three $\mathrm{dm}^{3}$ each). The stocking densities were 330 larvae per tank.

Tanks were supplied with recirculated and filtered water with the flow rate of $0.2 \mathrm{dm}^{3}$ per minute. Temperature of water was $14 \pm 1{ }^{\circ} \mathrm{C}$. A constant illumination of tanks was used from7.00 to 20.00 . In the same time larvae were fed manually every hour. Tanks were cleaned once daily at 18.00. Larval mortality was registered every day. Experiment lasted for 20 days.

For growth analysis the larvae were sampled every three days since 5 th day of rearing.

After preservation in $4 \%$ formaldehyde solution they were weighed and measured. Larval developmental advancement (LDS) according to Luczynski et al. [25] was also determined. The significance of the differences between feeding groups was evaluated by Duncan's multiple test.

Specific growth rate (SGR) was calculated from the equation: $\mathrm{SGR}=100\left[\left(\operatorname{InW}_{2}-\operatorname{InW}_{1}\right) / \mathrm{t}\right]$

Where

$\mathrm{W}_{1}$ - is average individual weight in $\mathrm{mg}$ at the beginning of rearing,

$\mathrm{W}_{2}$ - is average individual weight in $\mathrm{mg}$ at the end of rearing, and $\mathrm{t}-$ is duration of rearing in days.

\section{Results}

At the end of the experiment the statistical differences $(P<0.05)$ between feeding groups both in average weight and length of larvae were observed (Table 1). Larvae fed dry diet with $1.5 \mathrm{ppm}$ T3 reached mean weight of $41.4 \mathrm{mg}$ and length of $18.0 \mathrm{~mm}$, while those fed with $10 \mathrm{ppm}$ T3 had $25.2 \mathrm{mg}$ and $16.8 \mathrm{~mm}$, respectively. Fish in the control group reached size of $32.3 \mathrm{mg}$ and $17.6 \mathrm{~mm}$. Specific growth rate values ranged from $9.85 \%$ per day in larvae fed with 10 ppm T3 to $12.35 \%$ per day in group fed with 1.5 ppm T3 in the diet (Table 1).
Table 1. Results of Coregonus lavaretus larvae rearing on dry diet with T3 supplementation. Standard deviations in parentheses, means with the same superscript letter are not significantly different ( $P<0.05$, Duncan's multiple test).

\begin{tabular}{|c|c|c|c|c|c|c|}
\hline \multirow{2}{*}{$\begin{array}{l}\text { Day of } \\
\text { rearing }\end{array}$} & \multicolumn{6}{|c|}{ Feeding groups (T3 level in ppm) } \\
\hline & 0 & 0.5 & 1.5 & 3 & 5 & 10 \\
\hline \multicolumn{7}{|c|}{ Average body weight in $\mathrm{mg}$} \\
\hline 8 & $10.5(4.0)^{\mathrm{a}}$ & $15.7(3.1)^{\mathrm{a}}$ & $16.7(6.2)^{b}$ & $12.3(3.3)^{\mathrm{ab}}$ & $10.0(5.1)^{\mathrm{a}}$ & $9.0(2.6)^{\mathrm{a}}$ \\
\hline 14 & $26.8(9.4)^{\mathrm{a}}$ & $25.6(7.4)^{\mathrm{a}}$ & $25.9(3.8)^{\mathrm{a}}$ & $23.1(8.1)^{a}$ & $29.7(11.5)^{\mathrm{a}}$ & $22.5(5.8)^{\mathrm{a}}$ \\
\hline 20 & $32.3(15.5)^{\mathrm{bc}}$ & $36.6(13.6)^{c d}$ & $41.1(18.5)^{d}$ & $28.9(12.1)^{\mathrm{a}}$ & $28.6(14.3)^{a}$ & $25.1(9.5)^{\mathrm{a}}$ \\
\hline \multicolumn{7}{|c|}{ Average total length in $\mathrm{mm}$} \\
\hline 8 & $13.0(1.6)^{a}$ & $13.9(1.6)^{\mathrm{a}}$ & $13.8(1.1)^{\mathrm{a}}$ & $13.3(1.0)^{\mathrm{a}}$ & $12.4(1.5)^{\mathrm{a}}$ & $12.7(1.1)^{\mathrm{a}}$ \\
\hline 14 & $16.2(1.5)^{a}$ & $16.4(1.4)^{\mathrm{a}}$ & $16.2(0.6)^{a}$ & $15.7(1.6)^{a}$ & $16.5(1.4)^{a}$ & $15.5(0.9)^{\mathrm{a}}$ \\
\hline 20 & $17.6(2.4)^{\mathrm{ab}}$ & $17.7(2.2)^{\mathrm{ab}}$ & $18.0(2.1)^{b}$ & $17.1(2.3)^{\mathrm{a}}$ & $17.0(2.0)^{\mathrm{a}}$ & $16.8(4.6)^{\mathrm{a}}$ \\
\hline \multicolumn{7}{|c|}{ Average larval development stage - LDS } \\
\hline 8 & $2.5(0.1)^{\mathrm{a}}$ & $2.6(0.2)^{\mathrm{ab}}$ & $2.8(0.3)^{\mathrm{ab}}$ & $2.9(0.2)^{b}$ & $2.7(0.3)^{\mathrm{ab}}$ & $2.8(0.3)^{b}$ \\
\hline 14 & $4.3(0.3)^{\mathrm{a}}$ & $4.4(0.2)^{a b}$ & $4.7(0.3)^{c}$ & $4.6(0.2)^{\mathrm{bc}}$ & $4.6(0.2)^{c}$ & $4.5(0.1)^{c}$ \\
\hline 20 & $5.4(1.0)^{\mathrm{ab}}$ & $5.6(0.8)^{\mathrm{bc}}$ & $5.8(0.7)^{c}$ & $5.5(1.0)^{\mathrm{bc}}$ & $5.3(0.9)^{\mathrm{ab}}$ & $5.2(0.8)^{\mathrm{a}}$ \\
\hline \multicolumn{7}{|c|}{ Final mortality in \% } \\
\hline 20 & $21.2(2.0)^{a}$ & $26.2(3.2)^{a}$ & $22.7(1.9)^{\mathrm{a}}$ & $24.7(2.3)^{\mathrm{a}}$ & $26.7(4.9)^{\mathrm{a}}$ & $42.2(3.4)^{\mathrm{a}}$ \\
\hline \multicolumn{7}{|c|}{ Specific growth rate - SGR (\% per day) } \\
\hline $1-20$ & 11.11 & 11.74 & 12.35 & 10.55 & 10.50 & 9.85 \\
\hline
\end{tabular}

From 5th day of rearing statistically significant differences in larval development stages (LOS) were also observed (Table

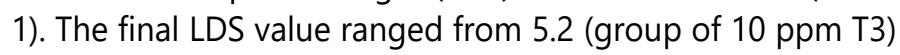
to 5.8 (group of $1.5 \mathrm{ppm}$ T3). Larvae receiving the dose of 1.5 ppm T3 exceed the others in all studied parameters, with exception group fed with $0.5 \mathrm{ppm}$ T3.

Final larval mortality ranged from $21.2 \%$ in control group to $42.3 \%$ in group fed dry diet with $10 \mathrm{ppm} \mathrm{T3} \mathrm{(Table} \mathrm{1).} \mathrm{There}$ were no statistical differences in mortality between feeding groups.

\section{Discussion}

Determination the best hormone level in the diet is probably the most important problem in studies on hormonal stimulation of growth. But results reported by different authors are difficult to compare. Different experiments were taken on various fish species and in various age classes. Moreover, time of rearing lasted from 20 (this study) to 112 days (coho salmon - 9). It seems to be typical in case of using of hormonal growth stimulators in fish diets $[5,9,26,27]$.

Designed in our experiment the best level of triiodothyronine in coregonid starter diet was about $1.5 \mathrm{ppm}$. This level was unexpectedly low, but practically has decided about growth of larvae. Nearing value of stimulation in coho salmon (increase of growth by 35\%) and American eel fry (increase by $21 \%$ ) was observed after long term administration, but doses were of 100 and 60 ppm T3 respectively $[9,10]$. In other our experiment the use of $1.5 \mathrm{ppm} \mathrm{T3}$ enhanced of Coregonus albula larval growth gain by $11-12 \%$ in relation to control [28].

Administration of five ppm T3 improved specific growth rate, protein conversion ratio and appetite in Red Sea bream fingerlings [12]. However, the same level of T3 improved only by $3 \%$ weight of channel catfish fry [11]. Optimal stimulating level of T3 in the diet is probably a species' attribute. This initially optimal level changes in course of ontogenesis too. 
Administration of T3 affected more on advancement of development in larval Coregonus lavaretus than on the size parameters (weight and length). Larvae receiving $10 \mathrm{ppm}$ T3 in the diet were more advanced in development until 17th day of rearing than control fish. By the whole experiment they were smaller than controls. It was rather symptomatic, because Luczynski et al. [25] found strong mathematic correlation between length of larvae and LDS in four species of coregonid fish. Kobuke et al. [29] and Specker [30] pointed out that thyroid hormones have exerted deciding influence on rate and course of fish larval development. The administration of thyroxine by immersion has accelerated metamorphosis in flounder and carp larvae $[31,32,33]$. Lack of correlation between size of Coregonus lavaretus larvae and their LDS have confirmed above observations.

Higgset al. [9] and Woo et al. [12] observed decrease of feeding coefficient in fish fed T3 supplemented diet. Furthermore, Woo et al. [12] noted an increase of activity of some digestive enzymes like lipase, $\alpha$-amylase and disaccharases in $T 3$ treated fish. Other authors reported about influence of thyroid hormones administration on lipid [34] and protein [35]. Different data were very contradictory $[4,6,36]$. So the mechanism of stimulating T3 effect on fish growth has been unclear yet.

This experiment showed that the use of 3,5,3'-triiodothyronine may effectively stimulate growth of white fish larvae. In experimental group fed with $1.5 \mathrm{ppm}$ T3 average weigh to fish was 28\% higher than in control group. Similar results were also recorded by other authors in fry of cohosalm on [9], and in American eel [10].

Stimulating effect of $\mathrm{T} 3$ on growth of larval coregonids is less visible in comparison to methyltestosterone $[14,23,37]$. However, long term administration of androgens (including methyltestosterone) in the diet may lead to histopathological changes of many organs, like gonads, liver, alimentary tract and kidney $[6,11,38,39]$. Gannam \& Lovell [39] reported that pathological changes causing T3 administration in channel catfish fry were very slight in comparison with those caused by androgens. This confirms also our earlier results obtained for other coregonids. Administration of $5 \mathrm{ppm}$ methyltestosterone caused pathological changes in liver and kidney of Coregonus albula larvae [40]. Coregonus albulaand Coregonus lavaretus are very close species, Stimulation of Coregonus albula larval growth by T3 did not caused any changes in the internal organs [41]. But not yet similar detailed histological studies for Coregonus lavaretus larvae. After visual observations of larval body we suppose that the effect is similar. In general, it may also suggest that triiodothyronine is more harmless growth stimulator for fish' organism than androgens [42], but stimulation with $\mathrm{T} 3$ is less effective than male sex steroids. Further comparative studies on this problem are needed.

\section{Conclusions}

We conclude that the best results for larval growth enhancing were obtained at dose of $1.5 \mathrm{ppm}$ T3. Supplementation of dry starter diets for whitefish larvae with other T3 doses used in the experiment also enhances moderately larval growth and development (with exception of maximal dose $10 \mathrm{ppm} \mathrm{T3).}$

\section{Conflict of interest}

The authors have declared no conflict of interest.

\section{References}

1. Hirose K, Hibiya T. Physiological studies on growth-promoting effect on protein anabolic steroids on fish-I Effects on goldfish. Bulletin of the Japanese Society of Scientific Fisheries. 1968; 34: 466-472. doi: 10.2331/ suisan. 34.466

2. Hirose $K$, Hibiya T. Physiological studies on growth-promoting effect of protein anabolic steroids on fish. II. Effects of 4-chlorotestosterone acetate on rainbow trout. Bulletin of the Japanese Society of Scientific Fisheries. 1968; 34: 473-479. doi: 10.2331/suisan.34.466

3. Matty AJ, Cheema IR. The effect of some steroid hormones on the growth and protein metabolism of rainbow trout. Aquaculture. 1978; 14: 163-178. doi: 10.1016/0044-8486(78)90027-3

4. Donaldson EM, Fagerlund UHM, Higgs DA, McBride JR. Hormonal enhancement of growth. In: Hoar W S, Randall j R, Brett J R, eds. Fish Physiology. 1979; 8: 455-598.

5. Lone KP, Matty AJ. The effect of feeding methyltestosterone on the growth and body composition of common carp (Cyprinus carpio L.). General and Comparative Endocrinology. 1980; 40: 409-424. doi: 10.1016/0016-6480(80)90004-0

6. Higgs DA, Fagerlund UHM, Eales JG, McBride JR. Application of thyroid and steroid hormones as anabolic agents in fish culture. Comparative Biochemistry and Physiology. 1982; 738: 143-176. doi: 10.1016/03050491(82)90206-1

7. Schreck CB, Fowler LG. Growth and reproductive development in fall chinook salmon: effects of sex hormones and their antagonists. Aquaculture. 1982; 26: 253-263. doi: 10.1016/0044-8486(82)90161-2

8. McLean E, Sadar MD, Devlin RH, Souza LM, Donaldson EM. Promotion of growth in diploid and triploid coho salmon with parental delivery of a recombinant porcine somatotropin. Aquatic Living Resources. 1991; 4: 155-160. doi: 10.1051/alr:1991016

9. Higgs DA, Fagerlund UHM, McBride JR, Eales JG. Influence of orally administered of L-thyroxine or 3,5,3'-triiodo-L-thyronineon growth, food consumption and food conversion of underyearling coho salmon (Oncorhynchus kisutch). Canadian Journal of Zoology. 1979; 57: 10741079. doi: 10.1139/z79-261

10. Degani G, Gallagher ML. The influence of 3,3',5-triiodo-L-thyronine on growth, survival and body composition of slow growing development elvers (Anguilla rostrata L.). Comparative Biochemistry and Physiology.1986; 84(1): 7-11. doi: 10.1016/0300-9629(86)90034-4

11. Gannam AL, Lovell RT. Effects of feeding 17-a-methyltestosterone, 11ketosterone,17p-estradiol,and3,5,3'-triiodothyronineto channel catfish, Ictalurus punctatus. Aquaculture. 1991; 92: 377-388. doi: 10.1016/00448486(91)90043-7

12. Woo NYS, Chung ASB, Ng TB. Influence of oral administration of 3,5,3 triiodo-L-thyronine on growth, digestion, food conversion and metabolism of under year ling red sea bream, Chrysophrysmajor (Temminck \& Schlegel). Joumal of Fish Biology. 1991; 39: 459-468.

13. Yamazaki F. Application of hormones in fish culture. Journal of the Fisheries Research Board of Canada. 1976; 33(4): 948-958. doi: 10.1139/f76-122

14. Samsul Alam M, Zamal Uddin M. Effects of testosterone propionate on growth, survival and sex-ratio of African catfish (Clarias gariepinus Burchell). Bangladesh Journal of Fisheries Research. 1998; 2(1): 31-39.

15. Lakra WS, Ayyappan S. Recent advances in biotechnology applications to aquaculture. Asian-Australian Journal of Animal Science. 2003; 16(3): 455462. doi: 10.5713 /ajas.2003.455 
16. Volkoff $H$. The neuroendocrine regulation of food intake in fish: a review of current knowledge. Frontiers in Neuroscience. 2016; 10: 540. doi: 10.3389/ fnins.2016.00540

17. $\mathrm{Ng} \mathrm{KL}$, Lam CC, Kwong KWY, Dik DWN, Lai NCY. Enhancement of fish growth employing feed supplemented with recombinant fish growth hormone expressed in Bacillus subtilis. Journal of Biotechnolog. 2016; 11(1): 1-11. doi: 10.13140/RG.2.1.3832.3288

18. Minton BL. Drug induced fish: hormone causes tilapia to undergo sex change. Natural News. 2009.

19. Goubau A. The Aqu Advantage salmon controversy - a tale of aquaculture, genetically engineered fish and regulatory uncertainty. 2011.

20. Megbowon I, Mojekwu IO. Tilapia sex reversal using methyl testosterone (MT) and its effect on fish, man and environment. Biotechnology. 2014; 13: 213-216. doi: 10.3923/biotech.2014.213.216

21. Hixson SM. Fish nutrition and current issues in aquaculture: the balance in providing safe and nutritious seafood, in an environmentally sustainable manner. Journal of Aquaculture Research \& Development. 2014; 5: 3. doi: 10.4172/2155-9546.1000234

22. Whitaker A, Eales JG. Comparison of 3,5,3'-triiodo-L-thyronineabsorption from the intestinal lumen of the fast ed rainbow trout, Oncorhynchusmykiss. Fish Physiology and Biochemistry. 1993; 10: 431-441.

23. Mamcarz A, Chybowski L, Poczyczynski P, Dostatni D, Kozlowski J. Effect of methyltestosterone in a dry diet on the growth of Coregonus albula $\mathrm{L}$. larvae in tanks and cages, Archiv fur Hydrobiologie. Special Issues Advances in Limnology. 1995; 46: 339-347.

24. Poczyczynski P, Jara Z, Mamcarz A, Kozlowski J, Chybowski L. Mass rearing of Coregonus sp. larvae using 17-a-methyltestosterone as the growth stimulator. Acta Academiae Agriculturae AC Technicae Olstenensis, Protectio Aquarum et Piscatoria. 1995; 20: 83-101.

25. Luczynski M, Falkowski S, Kopecki T. Larval development in four coregonid species (Coregonus albula, C. lavaretus, C. muksun and C. peled). Finnish Fisheries Research. 1988; 9: 61-69.

26. Degani G, Gallagher ML. Effects of dietary 17 a-methyltestosterone and bovine growth hormone on growth and food conversion of slow- and normally-growing American elvers (Anguilla rostrata). Canadian Journal of Fisheries and Aquatic Sciences. 1985; 42: 185- 189. doi: 10.1139/f85-023

27. Simone D. The effect of synthetic steroid 17-alpha-methyltestosterone on growth and organ morphology of channel catfish (lctalurus punctatus). Aquaculture. 1990; 84: 81-93. doi: 10.1016/0044-8486(90)90302-4

28. Mamcarz A, Poczyczynski P, Kozlowski J, Chybowski L. Effects of 3,5,3'-triiodo L-thyronine in a dry diet on the growth and survival of Coregonus albula L. larvae in tanks. European Aquaculture Society, Special Publication. 1995; 24: 248-250.

29. Kobuke L, Specker JL, Bern HA. Thyroxine content of eggs and larvae of coho salmon, Oncorhynchus kisutch. Journal of Experimental Zoology. 1987; 242: 89-94. doi: 10.1002/jez.1402420112
30. Specker JL. Preadaptive role of thyroid hormones in larval and juvenile salmon growth, the gut and evolutionary considerations. American Zoologist. 1988; 28: 337-349. doi: 10.1093/icb/28.2.337

31. Inui $Y$, Miwa S. Thyroid hormone induces metamorphosis of flounder larvae. General and Comparative Endocrinology. 1985; 60: 50-454. doi: 10.1016/0016-6480(85)90080-2

32. Lam TJ. Role of thyroid hormone on larval growth and development in fish. In: Lofts B, Holmes W.N, eds. Current Trends in Comparative Endocrinology. 1985; 481-485.

33. Lam TJ, Sharma R. Effects of salinity and thyroxine on larval survival, growth and development, Cyprinus carpio. Aquaculture. 1985; 44: 201212. doi: 10.1016/0044-8486(85)90244-3

34. Narayansingh T, Eales JG. The influence of physiological doses of thyroxine on the lipid reserves of starved and fed brook trout Salvelinus fontinalis (Mitchill). Comparative Biochemistry and Physiology. 1975; 52(3): 407-412. doi: 10.1016/0305-0491(75)90153-4

35. Matty AJ, Chaudry MA, Lone KP. Effect of thyroid hormones on the protein metabolism of Tilapiamossambica. General and Comparative Endocrinology. 1982; 46: 387.

36. Plisetskaya E, Woo NYS, Murat J. Thyroid hormones in cyclostomes and fish and their role in regulation of intermediary metabolism. Comparative Biochemistry and Physiology. 1983; 74(2): 179-187. doi: 10.1016/03009629(83)90586-8

37. Poczyczynski P, Dabrowski K, Kucharska K, Mamcarz A, Kozlowski J. Laboratory rearing of whitefish (Coregonus lavaretus) - comparative studies of Polish and foreign experimental starter diets. Polish Archives of Hydrobiology. 1990; 37: 397-411.

38. Zohar Y. Endocrinology and fish farming: Aspects in reproduction, growth, and smoltification. Fish Physiology and Biochemistry. 1989; 7: 395-405. doi: $0.1007 /$ BF00004734

39. Gannam AL, Lovell RT. Growth and bone in channel catfish fed a methyltestosterone in production ponds. Journal of the World Aquaculture Society. 1991; 22: 95-100. doi: 10.1111/j.1749-7345.1991.tb00721.x

40. Mamcarz A, Demska-Zakes K, Kozlowski J, Poczyczynski P, Chybowski L. The use of 17-alpha-methyltestosterone as larval fish growth stimulator: histological study. International Symposium of Aquaculture and Water Resource Management. 1994.

41. Demska-Zakes K, Mamcarz A, Poczyczynski P, Kozlowski J, Chybowski L. The use of 3,5,3'-triiodo-L-thyronine as larval fish growth stimulator: histological study. European Aquaculture Society, Special Publication. 1995; 24: 244-247.

42. Poczyczynski P, Kozlowski J, Mamcarz A, Kujawa R. Effect of simultaneous administration of 17-alpha-methyltestosterone and of 3,5,3'-triiodo-Lthyronine in starter diets on rearing of whitefish (Coregonus lavaretus $\mathrm{L}$.) larvae. Archives of Polish Fisheries. 1998; 6(1): 51-68. 